\title{
ANALISIS PERBEDAAN KUALITAS PELAYANAN PADA PASIEN BPJS DAN PASIEN UMUM TERHADAP KEPUASAN PASIEN DI RAWAT JALAN RSUD KOTA SURAKARTA
}

\author{
Aisah Ayu Nur Pertiwi \\ Program Studi Magister Manajemen, Universitas Muhammadiyah Surakarta \\ Jl. Ahmad Yani, Pabelan Surakarta 57102 \\ Email: aisahnurse313@gmail.com
}

\begin{abstract}
Abstrak
Tujuan penelitian adalah mengetahui perbedaan kualitas pelayanan berdasarkan keselamatan pasien, efektivitas dan efisiensi, dan berorietasi pada pasien, serta kepuasan pasien antara pasien yang menggunakan BPJS dan umum. Penelitian dilakukan sebanyak 60 responden yang terdiri dari 30 pasien BPJS dan 30 pasien umum di rawat jalan RSUD Kota Surakarta. Analisis data yang digunakan adalah uji independent t-test kemudian dianalisis pengaruh antara variabel independen terhadap dependen menggunakan analisis regresi berganda. Hasil penelitian menyebutkan adanya perbedaan yang signifikan kualitas pelayanan berdasarkan keselamatan pasien, efektivitas dan efisiensi, dan berorietasi pada pasien, serta kepuasan pasien antara pasien yang menggunakan BPJS dan umum, serta adanya pengaruh antara variabel keselamatan pasien, efektivitas dan efisiensi, dan berorietasi pada pasien terhadap kepuasan pasien. Dari hasil persamaan tersebut diketahui bahwa ketiga variabel independen yaitu keselamatan pasien, efektivitas dan efisiensi, dan pelayanan berorientasi pada pasien berpengaruh positif terhadap kepuasan konsumen. Artinya jika keselamatan pasien, efektivitas dan effisiensi, dan pelayanan berorientasi pada pasien, maka kepuasan pasien semakin tinggi.
\end{abstract}

Kata kunci: BPJS, berorientasi pada pasien, keselamatan pasien, kepuasan pasien

\begin{abstract}
The purpose of this study was to determine differences in the quality of service based on patient safety, effectiveness and efficiency, and patient centeredness, as well as patient satisfaction between patients using BPJS and general. The study was conducted as many as 60 respondents consisted of 30 patients BPJS and 30 general patients Rawat jalan Hospital Surakarta. Analysis of the data used is the independent t-test and analyzed the influence of the independent variable on the dependent using multiple regression analysis. The study says there are significant differences of quality of service based on patients safety, effective and efficiency, and patient centeredness, as well as patient satisfaction between patients using BPJS and general, as well as the influence of variable patient safety, effectiveness and efficiency, and patient centeredness to client satisfaction. Forming that the three independent variables are patient safety, effectiveness and efficiency, and patient centeredness have positive effect on customer satisfaction. This means that if patient safety, effectiveness and efficiensi and patient centeredness, the higher patient satisfaction.
\end{abstract}

Key word: BPJS, patients satisfaction, safety, patient centeredness 


\section{Pendahuluan}

Sakit merupakan hal yang tidak pernah diinginkan seseorang. Pengeluaran tidak terduga terkait dengan seseorang yang terkena penyakit, ataupun mengalami suatu kejadian yang tak terduga seperti kecelakaan harus mengeluarkan biaya untuk datang ke fasilitas kesehatan.

Tingginya biaya kesehatan semakin menyulitkan masyarakat untuk memperoleh layanan kesehatan. Salah satu metode yang dapat digunakan dalam meringankan beban pembiayaan kesehatan dengan menggunakan asuransi. Upaya telah dilakukan pemerintah dalam memberikan jaminan kesehatan untuk masyarakat seperti adanya Jaminan Kesehatan Nasional (JKN). Berdasarkan undang-undang nomor 24 tahun 2011, Badan Penyelenggara Jaminan Sosial (BPJS) akan menggantikan sejumlah lembaga jaminan sosial yang ada di Indonesia yaitu lembaga asuransi jaminan kesehatan PT. Askes Indonesia menjadi BPJS Kesehatan. Pada awal 2014, PT. Askes menjadi BPJS Kesehatan. BPJS diharapkan mampu memberikan pelayanan kesehatan kepada masyarakat lebih baik lagi dari tingkat awal hingga pelayanan paripurna (Putri, 2014).

Namun, masih banyak persoalan yang terjadi di rumah sakit terkait dengan pelayanan pasien yang menggunakan BPJS. Persoalan pertama BPJS Kesehatan sudah muncul sejak proses aktivasi kartu. BPJS menerapkan aturan bahwa kartu pengguna BPJS baru bisa aktif sepekan setelah pendaftaran diterima. Padahal sakit menimpa tanpa terduga dan tak mungkin bisa ditunda. Selanjutnya, rujukan lembaga jasa kesehatan yang ditunjuk BPJS Kesehatan juga terbatas dan tidak fleksibel

Menurut Pratiwi et al. (2014) kepuasan merupakan hasil evaluasi (penilaian) konsumen terhadap berbagai aspek kualitas pelayanan. Menyatakan kualitas pelayanan harus dimulai dari kebutuhan konsumen dan berakhir pada persepsi konsumen (Tjiptono dan Chandra, 2011). Kepuasan pasien atau peserta asuransi merupakan salah satu faktor yang dapat digunakan sebagai acuan dalam menentukan keberhasilan progam pelayanan. Hal ini berarti kualitas yang baik dari suatu layanan bukan berdasar pada persepsi penyedia jasa, tapi berdasarkan pada persepsi konsumen karena konsumenlah yang menikmati pelayanan yang diberikan oleh perusahaan (Trisnawati, 2015).

Menurut Wijono (dalam Safrudin, 2012) pelayanan kesehatan yang bermutu dengan menggunakan strategi utama persaingan perusahaan yaitu berorientasi pada kepuasan pasien akan mampu bertahan di tengah persaingan global yang semakin kuat. Baik secara subjektif maupun ojektif dimensi mutu diukur dengan enam dimensi yaitu safety, effective, effisiency, timeliness, patient centeredness, dan equity (Cahyono, 2008). Penelitian hanya mengambil variabel safety, effective dan effisiency menjadi satu kesatuan, serta patient centeredness.

Rumah sakit dituntut terakreditasi dan berstandar internasional, maka akreditasi JCI (Joint Commision International) memiliki standar bahwa keselamatan pasien dan peningkatan mutu merupakan tonggak akreditasi internasional tersebut. Di samping itu menurut peraturan presiden nomor 12 Tahun 2013 pasal 42 menyebutkan bahwa pelaksanaan pelayanan kesehatan pada peserta JKN harus memperhatikan mutu pelayanan dan berorientasi pada keamanan pasien, efektivitas pelayanan, kesesuaian dengan kebutuhan pasien, dan efisiensi biaya.

Menurut Trisnawati (2015), terdapat perbedaan bermakna antara harapan dan persepsi responden pada masing-masing dimensi pada masa pelaksanaan Askes dan JKN dengan nilai sig 0,000 (CI 95\%). Gap terbesar pada masa Askes terdapat pada dimensi reliability (keandalan) dengan skor gap yaitu -0,87 dan gap terbesar pada masa JKN juga terdapat pada dimensi reliability (keandalan) dengan skor gap -1,49. Selain itu, hasil penelitian juga menunjukkan bahwa terdapat perbedaan bermakna antara kepuasan responden pada masa Askes dan JKN dengan nilai sig 0,004 (CI 95\%). Perbedaan nilai gap kepuasan pada masa Askes dan JKN terbesar 
pada dimensi reliability (keandalan) dengan skor gap 0,62.

Berbagai masalah yang dipaparkan, seperti berlakunya rujukan berjenjang dan pembatasan diagnosis tertentu terhadap pasien yang menggunakan BPJS untuk berobat di RSUD Kota Surakarta, tuntutan rumah sakit meningkatkan kualitas pelayanan, serta mengutamakan kepuasan pasien dalam memberikan pelayanan, maka penelitian ini mengambil judul Analisis Perbedaan Kualitas Pelayanan pada Pasien BPJS dan Pasien Umum Terhadap Kepuasan Pasien di Rawat Jalan RSUD Kota Surakarta.

Tujuan penulisan ini adalah (1) Untuk mengetahui tingkat perbedaan pelayanan berdasarkan dimensi safety (keselamatan pasien) pada pasien yang menggunakan BPJS dan umum di rawat jalan RSUD Kota Surakarta, (2) Untuk mengetahui tingkat perbedaan pelayanan berdasarkan dimensi effective and efficiency (efektivitas dan effisiensi) pada pasien yang menggunakan BPJS dan umum di rawat jalan RSUD Kota Surakarta, (3) Untuk mengetahui tingkat perbedaan pelayanan berdasarkan dimensi patient centeredness (berorientasi pada pasien) pada pasien yang menggunakan BPJS dan umum di rawat jalan RSUD Kota Surakarta, (4) Untuk untuk mengetahui tingkat perbedaan kepuasan pasien pada pasien yang menggunakan BPJS dan umum di rawat jalan RSUD Kota Surakarta, dan (5) Untuk mengetahui pengaruh keselamatan pasien, efektivitas and efficiensi, pelayanan berorientasi pada pasien terhadap kepuasan pasien BPJS dan umum di rawat jalan RSUD Kota Surakarta.

\section{Tinjuan Pustaka}

\section{Kepuasan Pasien}

Kepuasan pasien merupakan sesuatu yang sangat penting bagi penyedia jasa layanan kesehatan atau rumah sakit. Jika rumah sakit ingin tetap bertahan dalam persaingan global, rumah sakit milik pemerintah ataupun rumah sakit milik swasta harus semakin bersaing secara kompetitif guna meningkakan kepuasan pelanggan (Yuniarti, 2015).

Pendekatan jaminan mutu layanan kesehatan yang diterapkan, memposisikan kepuasan pasien menjadi bagian yang integral dan menyeluruh dari kegiatan jaminan mutu layanan kesehatan. Artinya, pengukuran tingkat kepuasan pasien menjadi tidak dapat dipisahkan dari pengukuran mutu layanan kesehatan. Konsekuensi dari pola pikir yang demikian adalah kepuasan pasien menjadi salah satu dimensi mutu layanan kesehatan yang penting (Pohan, 2007).

Kepuasan pasien adalah tingkat perasaan yang timbul setelah seorang pasien mendapatkan pelayanan kesehatan dan membandingkan dengan apa yang diharapkan (Pohan, 2007). Mutu atau kualitas sering disetarakan dengan kepuasan pelanggan. Kepuasan merupakan hasil evaluasi (penilaian) konsumen terhadap berbagai aspek kualitas pelayanan. Penilaian kualitas dilakukan dengan membandingkan antara harapan dengan kinerja nyata kualitas yang dirasakan. Semakin kecil kesenjangan antara harapan dengan kualitas yang dirasakan, maka akan semakin tinggi kepuasan. Sebaliknya, semakin lebar kesenjangan harapan dengan kinerja kualitas, maka tingkat kepuasan pun akan semakin rendah (Kotler dan Keller, 2007). Dapat diartikan bahwa pelanggan puas apabila yang diterima lebih besar daripada yang diharapkan (perceived $>$ expected) (Cahyono, 2008).

Kemauan atau keinginan pasien dan masyarakat dapat diketahui melalui survei kepuasan pasien. Pengalaman membuktikan bahwa transformasi ekonomi pasti akan mengubah keinginan dan kebutuhan masyarakat terhadap layanan kesehatan. Survei kepuasan pasien menjadi penting dan perlu dilakukan bersamaan dengan pengukuran dimensi mutu layanan kesehatan yang lain (Pohan, 2007).

\section{Kualitas Pelayanan}

Menurut Wijono (dalam Safrudin, 2012) pelayanan kesehatan yang berkualitas dengan 
menggunakan strategi utama persaingan perusahaan yaitu berorientasi pada kepuasan pasien akan mampu bertahan di tengah persaingan global yang semakin kuat (Trisnaeni, 2014).

Mutu merupakan sebuah kata yang penting bagi penyedia jasa yaitu suatu tindakan yang harus dikerjakan dengan baik. Aplikasi mutu sebagai sifat dari penampilan produk atau kinerja merupakan bagian utama strategi perusahaan dalam rangka meraih keunggulan yang berkesinambungan, baik sebagai pemimpin pasar ataupun sebagai strategi untuk terus tumbuh (Kotler, 2009).

Menurut Zeithaml dan Bitner (dalam Pratiwi 2014), untuk mengetahui konsep dari kualitas pelayanan menyebutkan bahwa mutu pelayanan yang diterima konsumen dinyatakan dalam ukuran besarnya ketidaksesuaian antara harapan dan keinginan dengan tingkat persepsi mereka terhadap pelayanan yang akan diperoleh. Persepsi dari kualitas pelayanan selanjutnya diinterpretasikan pada perbedaan antara persepsi mutu pelayanan dan harapan yang akan diterima oleh konsumen.

Mutu pelayanan merupakan suatu indikator pelayanan kesehatan yang menjadi salah satu indikator penentu citra institusi pelayanan kesehatan di masyarakat. Kualitas RS dijadikan sebagai jasa kesehatan pada kualitas pelayanan medis dan keperawatan yang diberikan kepada pasien dengan menggunakan strategi kegiatan jaminan mutu.

Baik secara subjektif maupun objektif dimensi mutu diukur dengan enam dimensi:

a. Safety atau Keselamatan Pasien $\left(\mathrm{X}_{1}\right)$

Menurut Permenkes No. 1691 tentang Keselamatan Pasien Rumah Sakit menyebutkan bahwa keselamatan pasien merupakan suatu sistem di mana rumah sakit membuat asuhan pasien dengan aman yang meliputi identifikasi, assasmen risiko, dan pengelolaan segala sesuatu yang berhubungan dengan pasien, pelaporan dan analisis insiden, kemampan belajar dari insiden, dan implementasi untuk meminimalkan terjadinya risiko dan mencegah cidera yang disebabkan oleh suatu tindakan.

Keselamatan pasien adalah bagian dari mutu. Fokus perbaikan pelayanan manajemen penanganan pengurangan rasa sakit pada pasien merupakan suatu implikasi tindakan guna memperbaiki kualitas pelayanan dan meningkatkan kepuasan pasien (Glowacki, 2015).

Keselamatan pasien memiliki dampak yang langsung dapat dirasakan oleh pasien akibat dari pelayanan rumah sakit. Pelayanan yang bermutu sudah pasti tidak akan mencederai pasien dan sudah pasti aman. Sebaliknya layanan yang aman belum tentu bermutu, belum tentu bebas dari kesalahan. Menurut IOM, keselamatan pasien didefinisikan sebagai layanan yang tidak menciderai atau merugikan pasien (safety is defined as freedom from accidental injury) (Cahyono, 2008).

\section{b. Effective and Efficiency atau Efektifitas dan Efisiensi $\left(\mathrm{X}_{2}\right)$. \\ Secara teknis, definisi efektif lebih} mudah dipahami bila dikaitan dengan penerapan klinis, yaitu efektivitas klinis. Uji klinis randomisasi (randomized controlled trial, RCT) adalah kunci penelitian efektivitas klinis. Jadi, pengertian efektif di sini identik dengan standar yang telah ditentukan atau standar terkini. Standar yang dianggap benar dan terkini adalah hasil penelitian yang bersifat RCT (paling baik) (Cahyono, 2008).

Peter F. Drucker, seorang pakar dalam manajemen modern memberikan arti kata efisien, yakni mengerjakan pekerjaan dengan benar (doing things right). Sistem pelayanan kesehatan dituntut untuk lebih efisien. Pelayanan yang efisien berarti menghindari segala pemborosan dalam penyediaan alat, mengurangi masa rawat inap, serta mengurangi pemeriksaan diagnostik dan terapi yang tidak perlu (Cahyono, 2008). 
Pasien sering dibingungkan dalam praktik keseharian di rumah sakit karena terdapat berbagai variasi pelayanan. Di rumah sakit yang sama dan kelas yang sama, namun dengan dokter bedah yang berbeda, operasi apendiktomi misalnya bisa berbeda baik dari sisi perawatan, obat yang digunakan, dan tarif jasa medis pun bisa berbeda. Hal ini terjadi karena tidak adanya standardisasi dalam pelayanan yang diberikan.

\section{c. Patient centeredness atau \\ Berorientasi pada Pasien $\left(\mathrm{X}_{3}\right)$ \\ Pelayanan yang berfokus pada pasien} bukan konsep yang baru, tetapi nilainilai ini telah diabaikan oleh para dokter. Kecenderungan yang terjadi saat ini berorientasi pada teknologi (technology centered), berpusat pada dokter (doctor centered), berpusat pada rumah sakit (hospital centered), dan berpusat pada penyakit (disease centered). Nilainilai pasien seperti harapan, perasaan, keinginan, dan kecemasan yang muncul selama interaksi pasien dengan dokter sering diabaikan. Ketidakpuasan, tuntutan malpraktik, dan cedera medis terjadi sebagai akibat pelayanan yang tidak berfokus pada pasien. Pelayanan yang berfokus pada pasien bertujuan untuk menciptakan hubungan dokter-pasien lebih seimbang (Cahyono, 2008).

Perawatan yang berfokus pada pasien merupakan harapan di lingkungan pelayanan pada saat ini. Pasien yang ditempatkan sebagai kelompok pertama dalam sistem kesehatan untuk mengoptimalkan kualitas dan keamanan pelayanan. Prinsip-prinsip pelayanan yang berpusat pada pasien memberikan rasa aman, efektif, efisien, tepat waktu, dan perawatan yang adil (Ricards \& Adam, 2015).

Kesembuhan pasien tidak hanya bergantung pada kebenaran diagnosis saja, melainkan juga tergantung pada hal lain seperti kepercayaaan. Era sudah berubah, pasien dan keluarga semakin pandai dan lebih mengerti haknya. Mereka ingin dilibatkan dalam pengambilan keputusan. Pola hubungan ini dikenal dengan nama partnership atau shared decision making.

\section{Metode}

Penelitian ini memakai jenis rancangan yang digunakan adalah survey yang bersifat deskriptif. Jenis penelitian causal comparative research atau case control study. Sampel responden mengambil seluruh sampel pasien umum sebanyak 30 orang yang ditemui di rawat jalan RSUD Surakarta dan sebagian dari pasien BPJS di rawat jalan RSUD Surakarta sebanyak 30 orang setelah diseleksi responden sesuai dengan tujuan dan masalah yang diteliti pada waktu yang telah ditentukan yang diseleksi menggunakan kriteria inklusi dan eksklusi.

Variabel bebas (independen) dalam penelitian ini adalah keselamatan pasien $\left(\mathrm{X}_{1}\right)$, effective and efficiency (X2), berorientasi pada pasien (X3). Variabel terikat (dependen) dalam penelitian ini adalah kepuasan pasien (Y). Teknik analisis pada penelitian ini menggunakan uji t-test membandingkan perbedaan kualitas pelayanan dan kepuasan pasien antara pasien BPJS dan umum kemudian menganalisis adanya pengaruh dimensi kualitas pelayanan terhadap kepuasan pasien menggunakan analisis regresi linier berganda dan koefisiensi regresi serta uji asumsi klasik Multikolinieritas, Heteroskedastisitas, dan Normalitas dengan menggunakan SPSS versi 23.

\section{Hasil Dan Pembahasan}

Penelitian menggunakan 60 responden yang terdiri atas 30 pasien BPJS dan pasien umum. Responden wanita sebanyak 34 pasien yang terdiri atas $16(47,06 \%)$ pasien BPJS dan $18(52,94 \%)$ pasien umum. Responden laki-laki sebanyak 26 pasien terdiri atas 14 $(53,85 \%)$ pasien BPJS dan $12(46,15 \%)$ pasien umum. Umur responden sebagian besar antara 31-60 tahun sebanyak 28 orang yang terdiri atas 14 (50\%) pasien BPJS dan 14 
(50\%) Umum. Distribusi pekerjaan responden yang menggunakan BPJS sebagian besar adalah PNS/TNI/POLRI dan swasta $61,5 \%$. Pasien umum sebagian besar adalah pelajar/ mahasiswa sebanyak 10 orang $(83,3 \%)$.

Berdasarkan uji beda, terlihat bahwa variabel keselamatan pasien untuk kelompok BPJS mempunyai nilai mean sebesar 16,77 lebih rendah dibanding keselamatan pasien umum dengan nilai $(\mathrm{p}=0.045<0.05)$ yang berarti ada perbedaan yang signifikan antara keselamatan pasien BPJS dengan keselamatan pasien umum. Nilai mean efektivitas dan efisiensi pelayanan kelompok BPJS diperoleh sebesar 15,90 lebih rendah dibanding umum yaitu 18,07 dengan $(p=0.038<0.05)$ yang berarti terdapat perbedaan yang signifikan antara efektivitas dan efisiensi pelayanan kelompok BPJS dengan kelopok umum secara signifikan. Nilai mean pelayanan berorientasi pada pasien BPJS sebesar 16,13 lebih rendah dari nilai mean pasien umum $(17,87)$ dan mempunyai nilai $(\mathrm{p}=0.013<0.05)$, ini menunjukkan terdapat perbedaan yang signifikan antara pasien BPJS dengan umum pada pelayanan yang berorientasi pada pasien. Terdapat perbedaan yang signifikan antara pasien BPJS dengan umum, hal ini terlihat pada nilai mean kepuasan pasien umum lebih tinggi $(20,50)$ dibanding pasien BPJS $(17,19)$.

Setelah diuji dengan independent t-test, data diolah kembali menggunakan analisis regresi linier berganda untuk mengetahui pengaruh variabel $\mathrm{x}$ terhadap $\mathrm{y}$.

Tabel 1. Analisis Regresi Berganda

\begin{tabular}{|c|c|c|c|c|c|c|}
\hline & \multirow[b]{2}{*}{ Model } & \multicolumn{2}{|c|}{$\begin{array}{c}\text { Unstandardized } \\
\text { Coefficients }\end{array}$} & \multirow{2}{*}{$\begin{array}{c}\text { Standardized } \\
\text { Coefficients } \\
\text { Beta }\end{array}$} & \multirow[b]{2}{*}{$\mathrm{t}$} & \multirow[b]{2}{*}{ Sig. } \\
\hline & & B & Std. Error & & & \\
\hline \multirow[t]{4}{*}{1} & $($ Constant $)$ & 4.887 & 2.276 & & 2.147 & 0.036 \\
\hline & Keselamatan pasien & 0.202 & 0.107 & 0.200 & 1.888 & 0.064 \\
\hline & Efektivitas dan Efisiensi & 0.406 & 0.094 & 0.467 & 4.318 & 0.000 \\
\hline & Berorientasi pada Pasien & 0.237 & 0.094 & 0.254 & 2.511 & 0.015 \\
\hline
\end{tabular}

Sumber: Output SPSS 23, 2016.

Berdasarkan hasil analisis seperti yang terlihat pada tabel 1 tersebut dapat dibuat persamaan regresinya sebagai berikut:

$Y=4,887+0,202 X_{1}+0,406 X_{2}+0,237 X_{3}$

1. Nilai koefisien regresi untuk variabel keselamatan pasien $\left(\mathrm{X}_{1}\right)$ sebesar positif 0,202 berarti bahwa setiap kenaikan variabel keselamatan pasien $\left(\mathrm{X}_{1}\right)$ akan menaikan kepuasan pasien.

2. Nilai koefisien regresi untuk variabel efektivitas dan efisiensi $\left(\mathrm{X}_{2}\right)$ sebesar positif 0,406 berarti bahwa setiap kenaikan variabel efektivitas dan efisiensi $\left(\mathrm{X}_{2}\right)$ akan menaikkan kepuasan pasien.

3. Nilai koefisien regresi untuk variabel pelayanan berorientasi pada pasien $\left(\mathrm{X}_{3}\right)$ sebesar positif 0,237 berarti bahwa setiap kenaikan variabel berorientasi pada pasien $\left(\mathrm{X}_{3}\right)$ akan menaikkan kepuasan pasien.
Dari hasil persamaan tersebut diketahui bahwa ketiga variabel independen yaitu keselamatan pasien, efektivitas dan efisiensi, dan pelayanan berorientasi pada pasien berpengaruh positif terhadap kepuasan konsumen. Artinya jika keselamatan pasien, efektivitas dan efficiensi, dan pelayanan berorientasi pada pasien, maka kepuasan pasien semakin tinggi.

a. Perbedaan pelayanan dimensi keselamatan pasien pada pasien yang menggunakan BPJS dan umum. Berdasarkan hasil uji independen t-tes yang telah dilakukan, ada perbedaan yang signifikan antara keselamatan pasien pasien BPJS dengan keselamatan pasien umum. Berarti pada pasien BPJS dan umum terdapat pelayanan yang berbeda yang berakibat pada kepuasan 
pasien yang berbeda pula. Menurut Zeithaml dan Bitner (2000), pelayanan yang bermutu sudah pasti tidak akan mencederai pasien dan sudah pasti aman. Sebaliknya layanan yang aman belum tentu bermutu, belum tentu bebas dari kesalahan. Menurut IOM, keselamatan pasien didefinisikan sebagai layanan yang tidak menciderai atau merugikan pasien (safety is defined as freedom from accidental injury). Pendekatan keselamatan pasien bertumpu pada tiga hal, yaitu mengurangi dampak cidera (mitigasi), memunculkan kesalahan atau KTD (agar ada pembelajaran), dan mencegah kesalahan, selain itu harus efektif dan harus efisien dalam member pelayanan pada pasien (Cahyono, 2008).

b. Perbedaan pelayanan dimensi efektivitas and efisiensi pelayanan pada pasien yang menggunakan BPJS dan umum. Hasil penelitian diperoleh nilai rerata pada variabel pelayanan untuk BPJS mempunyai nilai yang lebih rendah dibanding dengan umum. Nilai mean efektivitas dan efisiensi kelompok BPJS diperoleh sebesar 15,90 lebih rendah dibanding umum yaitu 18,07 yang berarti terdapat perbedaan yang signifikan antara efektivitas dan efisiensi kelompok BPJS dengan kelompok umum. Hal ini berarti pelayanan BPJS kurang efektif dan efisien. Selain itu, dikarenakan adanya rujukan lembaga jasa kesehatan yang ditunjuk BPJS Kesehatan juga terbatas dan tidak fleksibel. Peserta BPJS hanya boleh memilih satu fasilitas kesehatan untuk memperoleh rujukan dan tidak bisa ke fasilitas kesehatan lain meski samasama bekerja sama dengan BPJS.

c. Perbedaan pelayanan yang berorientasi pada pasien pada pasien yang menggunakan BPJS dan umum. Berdasarkan hasil uji independen t-tes yang telah dilakukan, diketahui bahwa variabel berorientasi pada pasien memiliki nilai mean pada pasien BPJS sebesar 16,13 lebih rendah dari nilai mean pasien umum $(17,87)$ dan mempunyai nilai $(\mathrm{p}=0,013<0.05)$, ini menunjukkan terdapat perbedaan yang signifikan antara pasien BPJS dengan umum pada berorientasi pada pasien. Menurut Satrinegara (2014), pasien jika memasuki rumah sakit dengan serangkaian harapan dan keinginan dan pada kenyataannya pengalamannya selama mendapatkan pelayanan di rumah sakit lebih baik seperti apa yang diharapkannya maka dia akan puas. Kondisi ini rumah sakit harus mengutamakan pihak yang dilayani (client oriented), karena pasien adalah klien yang terbanyak, maka banyak sekali manfaat yang dapat diperoleh suatu rumah sakit bila mengutamakan kepuasan pasien. Hasil penelitian didukung dengan hasil penelitian oleh Yuniarti (2015), yang menunjukan hasil dimensi responsiveness atau ketanggapan terhadap pasien mayoritas responden yang menggunakan BPJS mengatakan bahwa pelayanan yang diberikan baik. Hasil analisis dapat disimpulkan ada hubungan antara kualitas pelayanan rumah sakit pada dimensi responsiveness dengan tingkat kepuasan pasien BPJS selama menjalani perawatan di Ruang Perawatan RSUD Sultan Syarif Mohamad Alkadrie Kota Pontianak.

d. Perbedaan kepuasan pasien pada pasien yang menggunakan BPJS dan umum. Pada variabel kepuasan pasien terdapat perbedaan yang signifikan antara pasien BPJS dengan umum. Pasien BPJS mempunyai kepuasan yang lebih rendah dibanding yang umum. Hal ini dikarenakan adanya pelayanan yang tidak efektif dan efisien. Menurut Yuniati (2015) kepuasan pasien merupakan sesuatu yang sangat penting bagi penyedia jasa layanan kesehatan atau rumah sakit. Jika rumah sakit ingin tetap bertahan dalam persaingan global, rumah sakit milik pemerintah ataupun rumah sakit milik swasta harus semakin bersaing secara kompetitif 
guna meningkatkan kepuasan pelanggan. Hasil penelitian ini didukung dengan hasil penelitian Trisnawati (2015), menunjukkan hasil penelitian bahwa terdapat perbedaan bermakna antara kepuasan responden pada masa Askes dan JKN dengan nilai signifikasi 0,004 (CI 95\%). Hasil penelitian lain yang mendukung yang dilakukan oleh Sari (2015), Berdasarkan nilai rata-rata pada tingkat kepuasan pasien umum diperoleh rerata sebesar 106,14 sedangkan pasien BPJS diperoleh rerata sebesar 66,62 dengan selisih keduanya sebesar 39,51. Penelitian ini dapat disimpulkan bahwa tingkat kepuasan pasien umum lebih baik dibandingkan dengan tingkat kepuasan pasien BPJS.

e. Pengaruh keselamatan, efektivitas and efisiensi, pelayanan berorientasi pada pasien terhadap kepuasan pasien BPJS dan umum di rawat jalan RSUD Kota Surakarta. Pada hasil regresi berganda diperoleh hasil variable independen mempengaruhi variabel dependen, dan yang paling signifikan adalah efektif dan efisien, sehingga dapat disimpulkan bahwa pasien BPJS maupun pasien umum beranggapan bahwa pelayanan yang terpenting menjadikan kepuasan pasien adalah pada pelayanan kesehatan yaitu mengenai keefektivan dan efisiensi yang dilakukan oleh rumah sakit, karena kualitas rumah sakit dibangun sebagai jasa kesehatan pada kualitas pelayanan medis dan keperawatan yang diberikan kepada pasien dengan menggunakan strategi kegiatan jaminan mutu (Kartini et al., 2016). Baik secara subjektif maupun ojektif dimensi mutu diukur dengan enam dimensi yaitu safety, effective, effisiency, timeliness, patient centeredness, and equity (Cahyono, 2008).

\section{Penutup}

Simpulan penelitian ini adalah (1) terdapat perbedaan kualitas pelayanan antara pasien BPJS dengan umum pada dimensi keselamatan pasien, (2) terdapat perbedaan kualitas pelayanan antara pasien BPJS dengan umum pada dimensi efektivitas dan efisiensi pelayanan, (3) terdapat perbedaan kualitas pelayanan antara pasien BPJS dengan umum pada dimensi pelayanan yang berorientasi pada pasien, (4) terdapat perbedaan kepuasan pasien antara pasien BPJS dengan umum, (5) variabel keselamatan, efektivitas dan efisiensi, dan pelayanan berorientasi pada pasien secara simultan berpengaruh positif terhadap kepuasan konsumen, dan (6) kepuasan pasien dipengaruhi oleh variabel keselamatan pasien, efektivitas dan efficiensi, dan pelayanan berorientasi pada pasien sebesar 43,40\% sedangkan sisanya sebesar $57,60 \%$ dipengaruhi oleh faktor lain.

Saran yang disampaikan adalah rumah sakit agar lebih meningkatkan pelayanan yang diberikan baik dari segi pelayanan oleh tenaga medis maupun kelengkapan sarana prasana yang dimiliki terutama untuk meningkatkan keefektifan dan efisiensi waktu pelayanan, dan bagi peneliti yang melakukan penelitian serupa diharapkan dapat melakukan penelitian yang lebih kompleks dan luas variabel maupun jumlah sampelnya.

\section{Daftar Pustaka}

Anonim. (2015). Presentase Penduduk Miskin Maret 2016 Mencapai 10,86\%. http://bps.go.id. Diakses pada tanggal 15 April 2016.

Cahyono, J.B. Suharjo B. 2008. Membangun Budaya Keselamatan Pasien dalam Praktik Kedokteran. Yogyakarta: Penerbit Kanisius.

Joint Commision International. 2016. International Patient Safety Goals. USA: Foundation of Accreditations. 
Kottler \& Keller, and Philip. 2009. Marketting Management Analysis, Planning, Implementations, and Control. Prentice Hall.

Kurnia. 2008. Analisis Kepuasan. Fisip UI, Jakarta, Indonesia.

, Nasution. 2016. Chapter II-Analaisis Kepuasan Pasien. www. Repository.usu.ac.id. Diakses pada tanggal 06 Oktober 2016.

Nooria, Widoningsih. 2008. Pengaruh Persepsi Kualitas Jasa Pelayanan Terhadap Kepuasan dan Loyalitas Pelanggan di RSU Saras Husada Purworejo. Skripsi (Tidak Diterbitkan). Fakultas Psikologi. Universitas Muhammadiyah Surakarta.

Notoatmodjo,S. 2010. Metodologi penelitian kesehatan. Jakarta: PT Rineka Cipta.

Nursalam. 2002. Manajemen Keperawatan: Aplikasi dalam Praktik Keperawatan Profesional. Jakarta: Salemba Medika.

Nursalam. 2008. Konsep dan Penerapan Metodologi Penelitian Ilmu Keperawatan. Jakarta: Penerbit Salemba Medika.

Peraturan Presiden No. 12. Tahun 2013 pasal 42. Kendali Mutu dan Biaya penyelenggaraan Jaminan Kesehatan. Jakarta: Presiden Republik Indonesia. Hal: 35.

Pohan, Imbalo S. 2007. Jaminan Mutu Layanan Kesehatan. Jakarta: Penerbit EGC.

Pratiwi, Kartika Gita. dkk. 2014. Analisis Mutu Pelayanan Rumah Sakit dan Pengaruhnya Terhadap Kepuasan Pasien Rumah Sakit Ibu dan Anak (RSIA) Andini di Pekan Baru, Vol. 1 No. 2 hal. 2.

Putri, Asih Eka. 2014. Paham BPJS (Badan Penyelenggara Jaminan Sosial). Jakarta: CV. Komunitas Pejaten Mediatama.

Sugiyono, 2010. Metode Penelitian Kuantitatif, Kualitatif, dan R\&D. Bandung: Alfabeta.

Suhartanto, D. 2001. Kepuasan Pelanggan. Pengaruhnya terhadap Perilaku Konsumen di Industri Perhotelan. Hal 42-47.

Susila \& Suryanto. 2015. Metodologi Penelitian Retrospective/ Ex Post Facto Case Control Causal Correlation. Klaten: BOSSSCRIPT.

Tjiptono, F. dan Chandra. 2011. Service, Quality, and Satisfaction, 3rd ed. Yogyakarta.

Trisnaeni, Febri. 2014. Hubungan Mutu Pelayanan dengan Tingkat Kepuasan Pasien Selama Berkunjung di Puskesmas Sungai Durian Kecamatan Sugai Raya Kabupaten Kubu Raya. Naskah Publikasi. Universitas Tanjungura, Pontianak, Indonesia.

Trisnawati, Komang. 2015. Analisis kepuasan pasien rawat jalan Pns Pada Masa Pelaksanaan Askes Dan Jkn Di Rsup Dr.sardjito Yogyakarta. Tesis, Universitas Gajah Mada, Yogyakarta, Indonesia.

Yuniarti, Siti. 2015. Hubungan Antara Kualitas Pelayanan Rumah Sakit dan Tingkat Kepuasan Pasien BPJS di Ruang Perawatan RSUD Sultan Syarif Alkadrie Kota Pontianak. Skripsi tidak dipublikasikan. Universitas Tanjungura, Pontianak, Indonesia. 